\title{
TINJAUAN TATA LETAK SURAT KABAR HARIAN LOKAL (ANALISIS ISI DAN HIERARCHI)
}

\author{
Nova Kristiana \\ Jurusan Desain, Fakultas Bahasa Dan Seni, Universitas Negeri Surabaya \\ Jl. Lidahwetan Surabaya \\ novakristiana@unesa.ac.id
}

\begin{abstract}
Newspaper is printed media that serves as a medium of information, and as a learning medium for the community. The Newspaper's layout has to be maintained constantly in every publication. Every issue in national newspaper layout has specific standard and generally prevails. In the other hand, local newspaper has the local content that must be raised in each edition. The constant of local newspaper layout needs to be understood as the uniqueness of the local content of the media itself. The purpose of this study are 1) to describe the grid elements of the local newspaper. 2) to describe the newspaper hierarchical. This is qualitative descriptive research. Data from the obtained newspaper were collected, grouped, compiled, explained and analyzed and then drawn conclusions. Descriptively, this study explained and developed the comprehending and the understanding of grid systems in the local newspaper. In this research focus on grid system Surya Daily Newspaper edition of March 2nd, 2017. The result is compiling grid element needs to classify the news by comprehending newspaper anatomy. So the arrangement of the layout has to be interesting so that the readers are able to read the news following the hierarchically.
\end{abstract}

Keywords: Newspaper, grid, Hierarchical, layout

\section{PENDAHULUAN}

Surat kabar merupakan media cetak yang berfungsi sebagai media informasi dan juga sebagai media pembelajaran bagi masyarakat. Surat kabar memiliki target audiens pembaca yang luas dan tidak spesifik. Surat kabar biasanya dicetak hitam putih, namun beberapa halaman yang khusus seperti cover, iklan fullpage atau spasial fullpage, dan halaman yang memuat foto dicetak berwarna. Mulai tahun 2015 ukuran surat kabar dibuat lebih kecil dari sebelumnya. Pada era digital dewasa ini berkembang Surat kabar yang diterbitkan secara online di internet. Bahkan beberapa Surat kabar memiliki versi cetak dan versi online sekaligus. pada dasarnya surat kabar cetak dan online memiliki kesamaan pada unsur yang ditampilkan namun berbeda media dan peletakannya.

Koran berasal dari bahasa Belanda "Krant" dan dari bahasa Perancis "courant" atau surat kabar adalah merupakan suatu penerbitan yang ringan dan mudah dibuang, biasanya dicetak pada kertas berbiaya rendah (disebut kertas koran), berisi berita-berita terkini dalam berbagai topik (even politik, kriminalitas, olahraga, tajuk rencana dan 
cuaca, atau bisa berisi komik, TTS dan hiburan lainnya), serta ada juga yang dikembangkan untuk bidang-bidang tertentu (berita industri tertentu, olahraga tertentu, seni atau partisipan kegiatan tertentu) (Suprayitno, 2012:595).

Surat kabar nasional adalah surat kabar yang terbit di seluruh bagian negara dimana kebanyakan negara mempunyai setidaknya satu surat kabar nasional. Di Indonesia Surat kabar berskala nasional salah satunya yaitu Kompas. Muatan beritanya luas mencakup pemberitaan satu wilayah negara. Bahkan di kompas ada halaman tersendiri yang memuat berita internasional. Surat kabar lokal juga mengikuti perkembangan berita nasional hanya saja lingkup penyebarannya hanya sebatas satu kota atau propinsi saja. Isinya pun menitikberatkan pada muatan beritaberita lokal.

Tataletak surat kabar semakin penting dalam menarik perhatian pembaca sehingga sejak tahun 1980an banyak surat kabar yang dicetak berwarna dan disertai grafis. Tata letak Surat kabar nasional memiliki standar yang umum dalam setiap edisi penerbitannya. Berbeda dengan media cetak lokal yang memiliki kekhasan dari muatan lokal yang harus diangkat dalam setiap edisinya. Keunikan dari muatan lokal Surat kabar lokal salahsatunya adalah tataletaknya.
Tata letak media cetak juga tidak lepas dari prinsip-prinsip desain yang melingkupinya (Tinarbuko, 2009:59). Prinsip tataletak merupakan rumus untuk merancang tataletak desain. Begitu pula desain media cetak yang di dalamnya terdapat prinsipprinsip tataletak desain yaitu: Sequence, Emphasis, Balance dan unity. Sequence merupakan urutan perhatian. Emphasis memberikan penekanan dalam desain. Balance mengatur keseimbangan. Sedangkan Unity menciptakan kesatuan (Rustan, 2008:74-75).

Sequence merupakan urutan perhatian pada layout atau aliran pandangan mata ketika melihat layout desain poster film. Sequence bisa disebut juga sebagai hirarki, flow atau aliran. Emphasis merupakan penekanan di bagian tertentu pada layout desain poster. Gunanya untuk lebih memfokuskan audience dalam melihat poster film tersebut. Sedangkan Balance merupakan teknik mengatur keseimbangan terhadap unsur-unsur layout tersebut. (Anggraini dkk., 2014:74-76)

Grid digunakan sebagai solusi untuk mengatasi permasalahan penempatan elemen-elemen visual dalam sebuah ruang desain. Sistem grid digunakan sebagai perangkat untuk mempermudah penempatan komposisi visual secara sistematis baik secara 
horizontal maaupun vertikal. (Shombing, 2015:204). Grid merupakan alat bantu yang bermanfaat untuk mengatur tataletak unsurunsur desain dan menjaga konsistensi dan kesatuan tataletak itu sendiri. (Rustan, 2008:68)

Grid digunakan untuk mengatur ruang dan informasi bagi pembaca berupa pemetaan rencana untuk proyek secara keseluruhan. Selain itu, grid merupakaan informasi dan cara untuk menjaga ketertiban. Hari ini, grid lagi dipandang sebagai alat yang penting, diandalkan oleh profesional yang baik baru untuk praktek dan dibumbui dengan pengalaman puluhan tahun. (Tondreau, 2009:8) Fungsi grid, selain alat pengaturan komposisi dalam ruang dua dimensi, grid dapat menciptakan sifat-sifat yang berkaitan dengan penampilan (performance) dalam bentuk desain, atau bisa menciptakan kesan (impression) tertentu; seperti sifat formal, mahal, murah dan seterusnya

\section{METODE PENELITIAN}

Jenis penelitian ini adalah penelitian deskriptif kualitatif. Metode penelitian kualitatif digunakan untuk meneliti tata letak atau grid system pada Surat kabar yang merupakan keadaan atau suatu peristiwa yang sedang berlangsung pada saat dilakukan penelitian. Data-data dikumpulkan, dikelompokkan, disusun, kemudian dianalisis dan selanjutnya ditarik kesimpulan.

Dalam penelitian ini fokus pada tataletak atau Grid System pada Surat kabar sebagai objek penelitiannya kemudian menganalisis struktur visual, alur keterbacaan atau Hierarchi dengan mengaitkan kajian teori yang telah ada. Sumber data utama yaitu Surat kabar Harian Surya yang terbit di Surabaya dimana peneliti berdomisili. Data tersebut dikumpulkan melalui teknik Dokumentasi yaitu mengumpulkan Surat kabar Harian Surya, dan studi literatur dengan cara mengumpulkan, membaca, dan mengamati serta mengkaji sumber data sekunder berupa buku dan website.

Analisis data dalam penelitian kualitatif merupakan proses penyusunan data secara sistematis yang diperoleh dari teknik pengumpulan data (observasi dan dokumentasi) kemudian dipelajari dan disimpulkan agar mudah dipahami (Sugiyono, 2011:335). Trianggulasi data merupakan teknik pemeriksaan keabsahan data yang memanfaatkan sesuatu yang lain, di luar data tersebut untuk keperluan pengecekan (Moleong, 1990 :178). Trianggulasi data yang dipergunakan pada penelitian ini menggunakan pemeriksaan data melalui sumber dengan membandingkan dan mengecek balik tingkat kepercayaan 
suatu informasi yang diperoleh melalui sumber dan waktu yang berbeda. Pada penelitian ini peneliti memvalidasikan data dengan mencocokkan dan menyilang informasi (crosscheck) antara beberapa sumber data yang ada, yaitu antara surat kabar dan majalah, pustaka dan informasi lainnya. Dari hasil mencocokan tersebut kemudian peneliti dan beberapa teman sejawat melakukan peer group discussion yaitu dilakukan dengan cara cara mendiskusikan hasil penelitian sementara, dalam bentuk diskusi analitik dengan rekan-rekan sejawat, yatitu teman dosen dalam satu bidang studi mendiskusikan hasil penelitian sementara, dalam bentuk diskusi analitik dengan rekanrekan sejawat, yatitu teman dosen dalam satu bidang studi.

\section{HASIL DAN PEMBAHASAN}

\section{Surat Kabar Harian Surya}

Surat kabar Harian Surya merupakan bagian dari media nasional yang menerbitkan, menyajikan berbagai ragam informasi kepada khalayak pembaca utama yakni masyarakat Jawa Timur. Ivan Harsono pada tanggal 24 oktober 1983 di jalan Bubutan 17 Surabaya, mendirikan PT. Antar Surya Jaya. Perusahaan yang bergerak di bidang penerbitan dan percetakan ini dimotori Post Kota Group. Seiring berjalannya waktu pada tahun 1986
Kelompok Kompas Gramedia (Jakarta) bergabung dan menerbitkan mingguan Surya. Tiga tahun kemudian yaitu tahun 1989 terjadi perubahan penerbitan yakni dari Mingguan ke Harian sampai sekarang ini, karena waktu penerbitan berubah maka nama pun berubah, dari Surat Kabar Mingguan Surya menjadi Surat Kabar Harian Surya. PT Antar Surya Jaya pindah lokasi ke jalan Basuki Rahmad 93-95 Surabaya. Akhirnya bulan Mei 2001, Kelompok Kompas Gramedia mengambil alih seluruh saham Post Kota di PT. Antar Surya Jaya. PT. Antar Surya Media Surabaya yang beralamat di jalan Rungkut Industri III No. 68 \& 70 Sier Surabaya (Huda,2011)

Surat kabar Harian Surya terbit 16-32 halaman berjumlah 7 kolom, bidang cetak berukuran lebar $325 \mathrm{~mm}$ dan tinggi $540 \mathrm{~mm}$, dengan jarak kolom/gutter $4 \mathrm{~mm}$. namun mulai tahun 2015 ukuran tersebut mengalami perubahan ukuran karena alasan ekonomis. Ukuran surat kabar harian Surya sekaran ini yaitu terdiri dari 28 halaman, 7 kolom, bidang cetak berukuran lebar $304 \mathrm{~mm}$ dan tinggi $540 \mathrm{~mm}$, dengan jarak kolom/gutter 4mm.

Segmentasi pemasaran pembaca Surya daerah Jawa Timur yaitu Orang Dewasa usia 20-60 tahun dengan prosentase 65\% Pria dan $35 \%$ wanita. Kriteria berita yang disajikan oleh Harian Surya antara lain: Baru, Tragedi atau Bencana, Konflik, Glamour, Seks, 
Human Interest, Kedekatan, Prominence. Yang terdiri dari beberapa nama antara lain: Internas, Bisnis, Female, Culibary, Politiik (Pilkada Serentak), Surya Lines, Hiburan, Tunjungan Life, Malang Life, Surya Kediri, Citizen Reporter, Sambang Kampung, dan Lapor Cak,

\section{Analisis Unsur Tata Letak Surat Kabar Harian Surya}

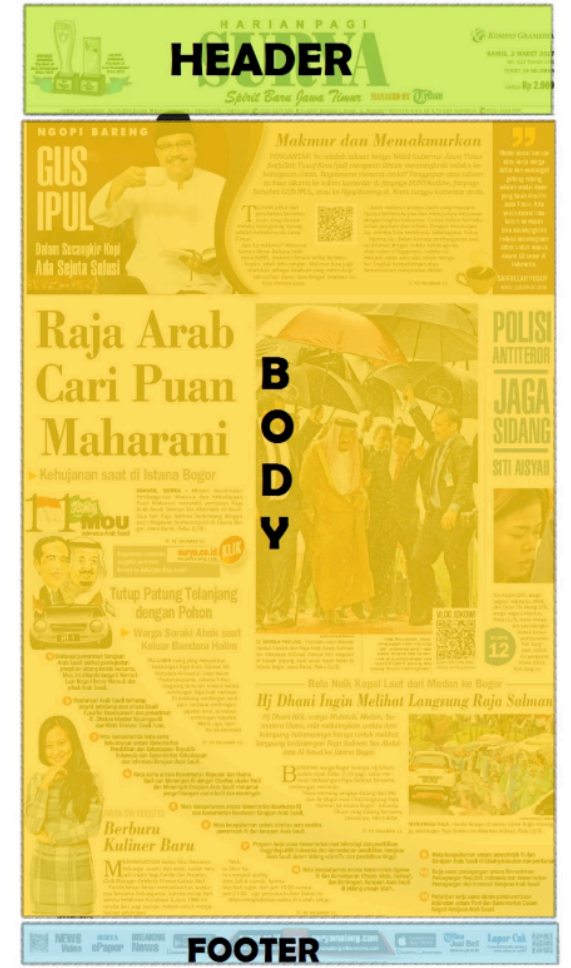

Gambar 1 Cover Surat Kabar Harian Surya edisi 2 Maret 2017

(Sumber : Penulis)

Surat Kabar Harian Surya edisi 2 Maret 2017 menerapkan 17 elemen tataletak desain. Yaitu Header yang terdiri dari Nameplate,
Jargon, Edisi terbit, dan Mondatoris. Body meliputi Judul/headline, Margin, Jump, Artwork, Bullets, Bodytext, Caption, Foto, Headshot. Footer meliputi Sponsor secara garis besar dibagi atas 3 bagian yaitu header (Kepala /Kop Surat Kabar), Body (Tubuh Surat Kabar), dan Footer (Kaki Surat Kabar)

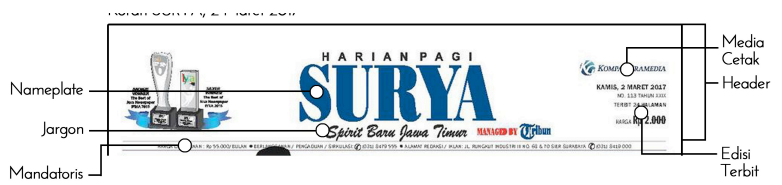

Gambar 2 Unsur layout pada Header (Sumber : Penulis)

\section{a. Header}

Header pada Surat Kabar Harian Surya terdiri dari :

1. Nameplate. Nameplate merupakan nama dari Surat Kabar. Diletakkan di bagian atas. Disertai keterangan tentang Surat Kabar tersebut.

Pada Nameplate diatas menggunakan dua jenis typeface yang berbeda. Ukurannya juga berbeda. Pada tulisan 'HARIAN PAGI' menggunakan jenis huruf San Serif dengan ukuran lebih kecil, berada tepat di atas Logo Surat kabar. Logotype Surat kabar 'SURYA' yang sekaligus sebagai nama dari Surat kabar tersebut berukuran paling besar ditampilkan dengan jenis huruf Serif. 
2. Jargon. Jargon merupakan kata-kata penyemangat, motto, suatu perusahaan. Jargon dipakai sebagai pendorong semangat suatu perusahaan dalam menata keberlangsungan hidup perusahaan dan kesejahteraan karyawannya. Supaya dalam suatu perusahaan terbentuk semnagat kerja yang tinggi dan konsekuensi serta kesatuan yang tinggi antar sesama karyawan. Sehingga terwujud satu tujuan utuh dalam perusahaan.

Jargon pada Header suratkabar di atas menggunakan jenis typeface script yang menyerupai tulisan tangan dan agak miring ke kanan. Jargon tersebut bertuliskan 'Spirit Baru Jawa Timur' dimaksudkan bahwa dengan hadirnya surat kabar Surya sebagai penyemangat baru bagi pembaca yang khususnya berada di wilayah Propinsi Jawa Timur sebagai target audiensnya.

3. Media Cetak. Media Cetak merupakan perusahaan yang menerbirkan Suratkabar. Pada keterangan media cetak diatas ditampilkan logo Kompas Gramedia dengan jenis typeface Slab serif. Ukuran lebih kecil berada di bagian kanan. Media Ceak ini menandakan bahwa penerbit suratkabar Surya adalah perusahaan Kompas Gramedia.

4. Edisi terbit. Edisi terbit sebagai keterangan surat kabar dalam penerbitannya. Didalam edisi terbit memuat hari dan tanggal penerbitan, nomor penerbitan, jumlah halaman serta harga setiap eksemplarnya.

Pada edisi terbit di atas menggunkan jenis typeface san serif dengan urutan waktu penerbitan berukuran sedang, nomor dan jumlah halaman agak kecil dari waktu, dan harga ditampilkan dengan ukuran paling besar. Susunan rata kanan dan diletakkan di posisi kanan di bawah Media Cetak.

5. Mondatoris merupakan keterangan jumlah penerbitan, harga berlangganan, alamat dam nomor telepon penerbit, dan lingkup penyebaran.

Mondatoris pada Suratkabar harian Surya menggunakan jenis huruf San serif berukuran kecil dan disusun dari kiri ke kanan dalam satu baris. Susunan ini sekaligus sebagai pembatas antara nameplate dan body suratkabar. 


\section{b. Body}

Cover pada Body Suratkabar terdiri dari berita-berita yang dimuat pada edisi tersebut. Berita yang ditampilkan disusun berdasarkan klasifikasi berita. Klasifikasi berita antara lain Headnews/Hotnews, Feature news, dan Berita sekilas. Headnews merupakan berita yang sedang panas di masyarakat, rasa ingin tahu pembaca paling tinggi di antara berita-berita lainnya. Misalnya kejadian yang menggemparkan, penemuan yang menghebohkan, kasus yang sedang viral. Headnews ditampilkan dengan ukuran Headline yang paling besar biasanya didukung oleh foto yang sama besarnya. Layoutnya diposisikan di center bagian atas. Feature news merupakan berita kedua lanjutan dari Headnews. Feature news biasanya berita-berita lain yang masih ada hubungannya dengan headnews. Namun jika tidak da berita terkait headnews maka muatan berita yang tingkat kepentingannya sedang daripada headnews ditampilkan. Di dalam layout biasanya ditampilkan pada sisi kanan kiri atau di bawah headnews. Berita sekilas merupakan hiasan berita pelengkap dari suratkabar, yang sudah memiliki halaman khusus pada suratkabar tersebut. Berita sekilas misalnya sosok atau tokoh, lifestyle, artis, dll.

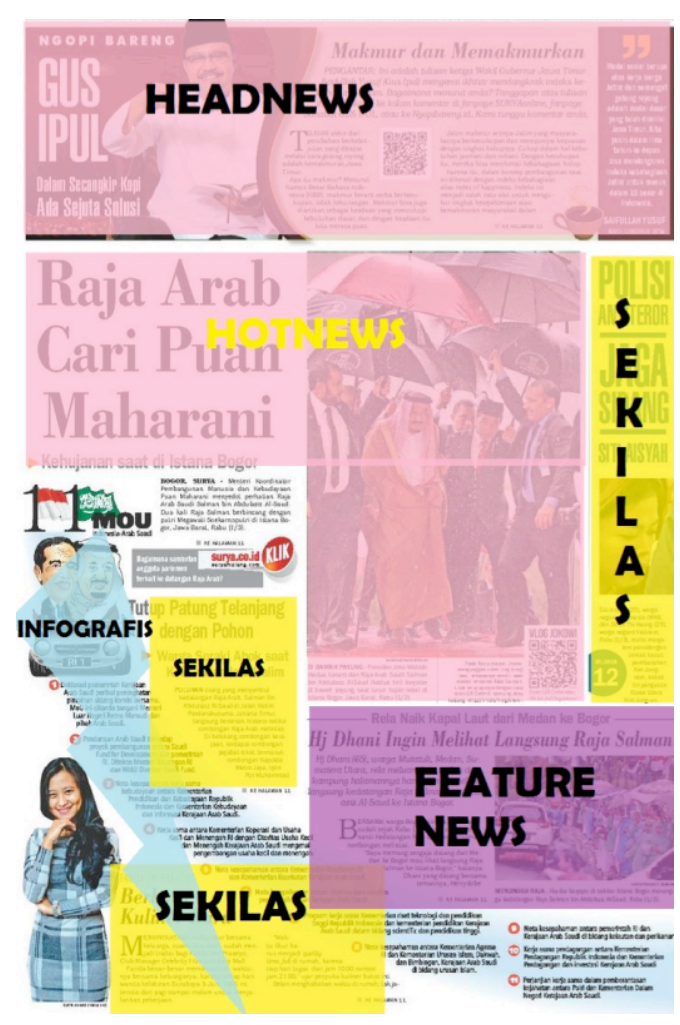

Gambar 3 Body Surat Kabar Harian Surya edisi 2 Maret 2017 (Sumber : Penulis)

Pada Body Surat Kabar Harian Surya yang terbit pada tanggal 2 Maret 2017, headnews dan hotnews ditampilkan berbeda dan saling mengisi. Headnews diletakkan di atas, berwarna dan memenuhi kolom. Muatan berita khusus untuk pembaca di wilayah Jawa Timur. Sedangkan Hotnews diletakkan di bawah headnews dengan headline berukuran lebih besar dan foto berukuran besar. Target pembaca lebih luas karena muatan berita umum namun samasama sedang dicari oleh masyarakat. Hampir memenuhi setengah dari body surat kabar. Tepat di bawah foto dari hotnews diletakkan featurenews sebagai berita pelengkap yang 
masih ada kaitannya dengan hotnews. Infografis yang berada di sebelah kiri dan memanjang ke arah kanan bawah, melengkapi adanya hotnews. Jadi antara hotnews, featurenews dan infografis informasi yang disampaikan masih berkaitan. Berita sekilas disusun terpisah-pisah antara kanan, kiri, dan bawah mengelilingi hotnews.

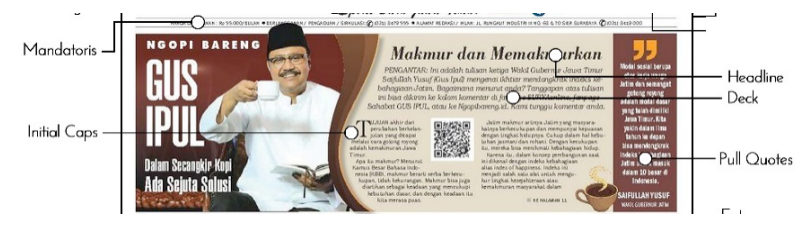

Gambar 4 Headnews Surat Kabar Harian Surya edisi 2 Maret 2017

(Sumber : Penulis)

Pada tampilan headnews di atas, terlihat ada tiga bagian besar yaitu bagian kiri (headline dan foto), bagian tengah (bodytext), dan bagian kanan quote dari materi yang disajikan. Headline atau Judul sebagai kunci untuk menggoda mata pembaca, headline menggunakan typeface berjenis San Serif berukuran variatif dengan membesarkan ukuran nama Tokoh 'GUS IPUL'. Headline disajikan berbeda dengan subheadline. Subheadline sebagai pendukung headline menggunakan typeface jenis Serif dengan family italic atau dimiringkan ke kanan. Deck atau Leading merupakan penjelasan singkat dari judul mengenai topik yang dibicarakan pada isi tulisan (bodytext). Deck menggunakan typeface berjenis sans serif sama dengan bodytext tetapi ukurannya lebih besar. Initial Cap atau drop cap merupakan huruf di awal paragraf yang dibesarkan. Sebagai awal pemberitaan. Initial Cap menggunakan jenis typeface sama dengan bodyext tetapi ukurannya paling besar. Pull Quote/Liftouts menarik sebagian perkaaan keluar dari badan sebuah teks. Pull quotes atau Lifttouts, juga menerangkan Bodyext atau garis besar dari isi. Pullquote menggunakan jenis typeface sama dengan bodyext tetapi ukurannya lebih kecil dari Deck dan lebih besar dari bodycopy. Foto sebagai pendukung dari materi berita yang disajikan. Disusun menyatu dengan headline. Pada bagian cover dari Surat Kabar Harian Surya Headnews ini berfungsi sebagai Aboove the fold merupakan halaman depan yang menjadi bagian atas saat dilipat

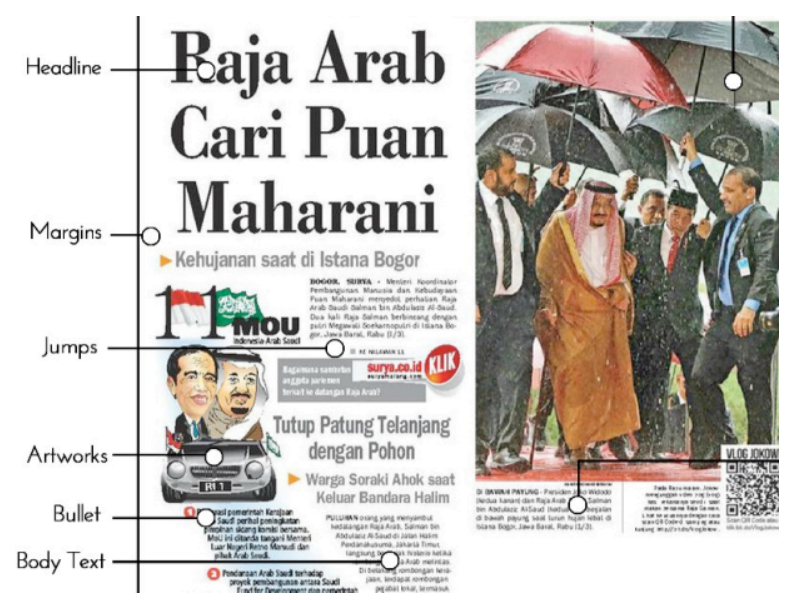

Gambar 5 Hotnews Surat Kabar Harian Surya edisi 2 Maret 2017

(Sumber : Penulis) 
Pada hotnews di atas, Foto sebagai pendukung dari materi berita yang disajikan. Disusun berdampingan dengan headline. Dalam hal ini peran antara typeface sebagai headline dengan ilustrasi memiliki kadar yang sama. Headline menggunakan typeface berjenis serif sama dengan bodytext tetapi ukurannya lebih besar. Headline memiliki lebar 2 kolom. Margin dibuat sebagai jarak antara materi berita dengan tepian media surat kabar. Jumps menunjukkan halaman sambungan dari bodytext. Jenis typeface sama dengan bodyext tetapi ukurannya lebih kecil. Infografis disajikan dalam bentuk artwork sebagai ilustrasinya. Bullet penjelasan dari infografis yang disajikan. Menggunakan typeface jenis san serif. Untuk menyatukan dengan artworks, bullet diberi penambahan warna background yang sekaligus berhubungan dengan artworks.

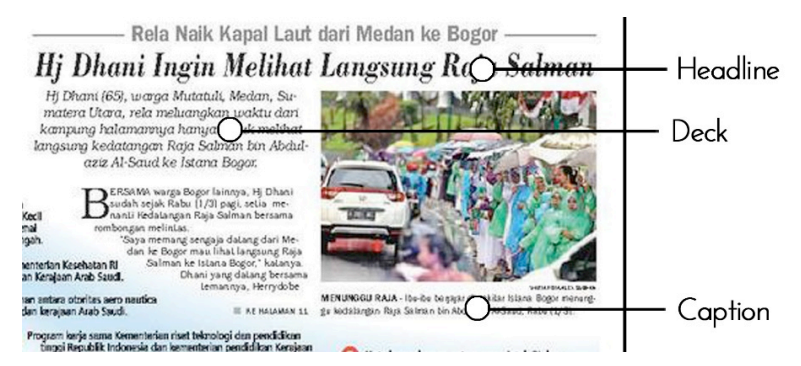

Gambar 6 Featurenews Surat Kabar Harian Surya edisi 2 Maret 2017 (Sumber : Penulis)

Headline menggunakan typeface berjenis serif sama dengan bodytext tetapi ukurannya lebih besar. Deck menggunakan typeface berjenis sans serif sama dengan bodytext tetapi ukurannya lebih besar. Caption menunjukkan keterangan dari foto. Jenis typeface sama dengan bodyext tetapi ukurannya lebih kecil. Bodytext/Bodycopy merupakan elemen layout yang paling banyak memberikan informasi terhadap topik bahasan. Pada dasarnya bodytext merupakan inti dari dari artikel secara lebih terperinci. Keberhasilan suatu bodytext ditentukan oleh judul dan deck yang menarik, sehingga pembaca meneruskan keingintahuan akan informasi yang lengkap, serta gaya penulisan yang menarik dari bahasan tersebut. Karena menjelasakan informasi secara panjang lebar mengenai artikel tersebut, bodytext ditulis dengan ukuran font paling kecil diantara judul. Initial Cap menggunakan jenis typeface sama dengan bodyext tetapi ukurannya paling besar. 


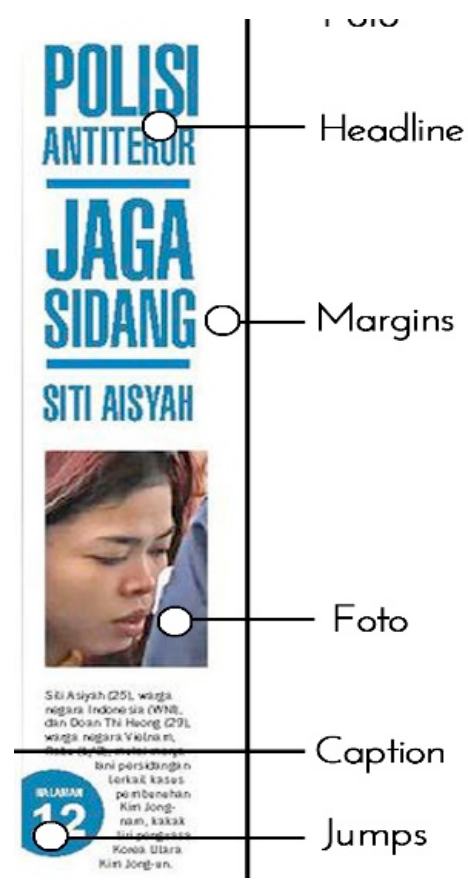

Gambar 7 Berita Sekilas Surat Kabar Harian Surya edisi 2 Maret 2017

(Sumber : Penulis)

Headline dibuat berukuran besar dengan dua varian ukuran. Menggunakan typeface San serif dengan penambahan garis bawah/underline sebagai penegas. Margin kanan dibuat berjarak dengan materi berita Foto merupakan ilustrasi pendukung tulisan dalam artikel. Foto dalam artikel ini sosok dari Siti Aisyah yang dijadikan berita dengan sudut pengambilan headshot. Caption menunjukkan keterangan dari foto. Jenis typeface sama dengan bodyext tetapi ukurannya lebih kecil. Jumps menunjukkan halaman sambungan dari bodytext yang memuat berita lebih lengkap.

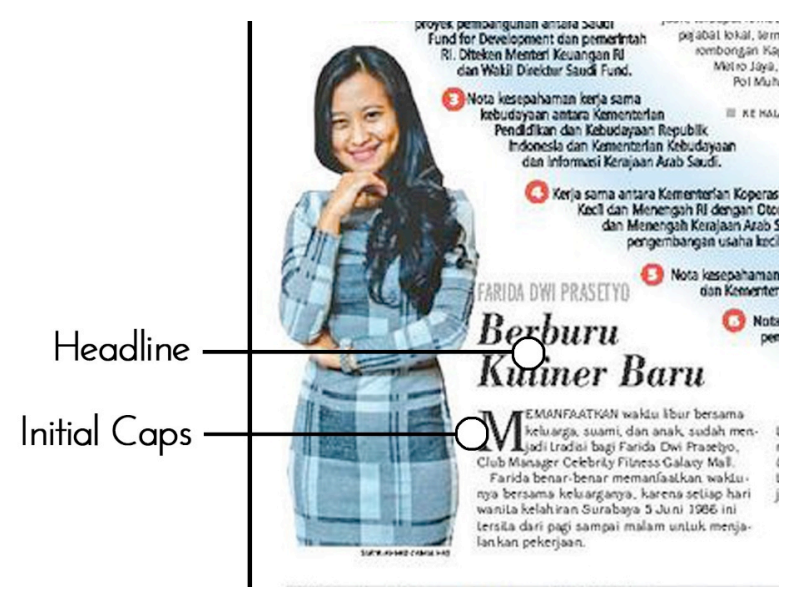

Gambar 8 Berita Sekilas Surat Kabar Harian Surya edisi 2 Maret 2017

(Sumber : Penulis)

Headline menggunakan typeface berjenis serif sama dengan bodytext tetapi ukurannya lebih besar. Initial Cap menggunakan jenis typeface sama dengan bodyext tetapi ukurannya paling besar. Foto merupakasn sosok Farida Dwi Prasetyo diambil dengan teknik medium shot.

\section{c. Footer}

Footer merupakan bagian bawah dari tampilan Suratkabar. Footer biasanya disebut sebagai kaki suratkabar. Footer terdiri dari Sponsorship, Nomor halaman, dan Running head. Sponsor, Iklan biasanya dipasang dibagian depan dan jenis iklan memilki halaman tersendiri dengan berbagai varian iklan kolom dan iklan baris sesuai tarif pemasangannya dan muatan iklannya Sponsorship Terletak di paling bawah tubuh Surat kabar. Nomor halaman/page number 
bertujuan untuk mengingatkan pembaca dalam mengingat halaman mana saja yang sudah dibaca. Running head merupakan judul buku, bab atau topik yang sedang dibaca, nama pengarang atau informasi lainnya yang berulang-ulang ada pada tiap halaman dan posisinya tidak berubah. Running head bisa ditempatkan di header atau footer.

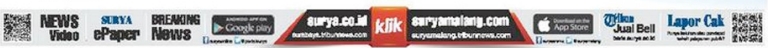

Gambar 9 Berita Sekilas Surat Kabar Harian Surya edisi 2 Maret 2017 (Sumber : Penulis)

Pada Surat Kabar Harian Surya 2 Maret 2017, footer hanya memuat sponsorship yang mendukung penerbitan dan distribusinya. Logo sponsorship disusun satu baris dari kiri ke kanan. Ukuran setiap bagian sponsor hampir sama. namun bagian center dibuat dengan ukuran paling besar sebagai daya tarik pembaca.

\subsection{Alur Baca / Hierarchical Surat Kabar Harian Surya}

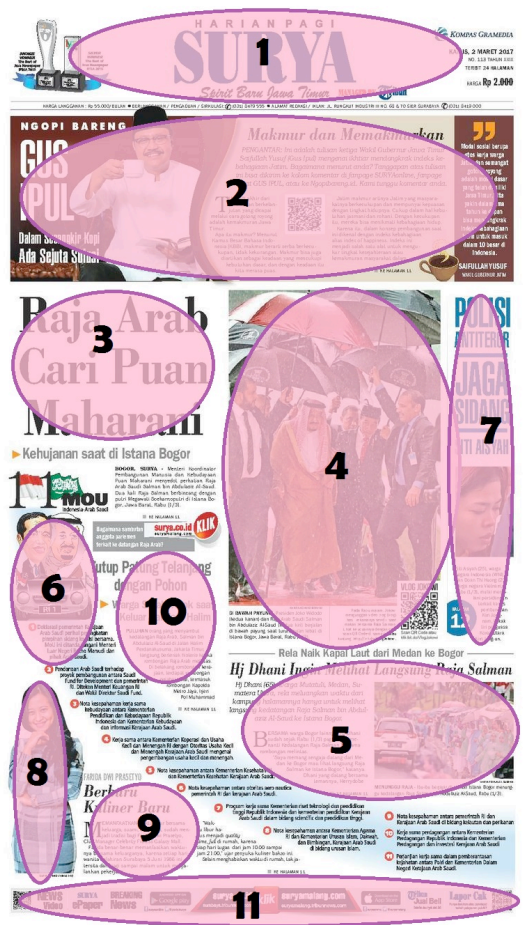

Gambar 10 ALur baca/hierarchical Surat Kabar Harian Surya edisi 2 Maret 2017 (Sumber : Penulis)

Pada cover Surat kabar Harian Surya menampilkan berita-berita yang dimuat di dalam satu paket eksemplar setiap kali terbit. Berita-berita diklasifikasikan selanjutnya diurutkan menurut penting tidaknya, menarik tidaknya berita tersebut. Alur keterbacaan dari Suratkabar Harian Surya yang terbt pada 2 maret 2007 berawal dari nameplate. Nameplate dilihat terlebih dahulu, karena sebagai identitas suatu surat kabar. Pembaca di Jawa Timur akan lebih tertarik dengan Surat Kabar Surya daripada Surat 
kabar harian Jogja, begitu juga sebaliknya. Masyarakat lokal Surabaya akan lebih tertarik membaca surat kabar harian Surya daripada Kompas. Karena muatan berita yang lebih lokal daripada nasional. Jadi pertama kali yang dilihat oleh pembaca adalah nameplate, karena dari nameplate akan tergambarkan berita yang akan dimuat. Selanjutnya yang dilihat oleh pembaca adalah headnews. Headnews lokal akan lebih awal dituju daripada headnews nasional. Pada cover Surat kabar harian Surya, headnews yang mengangkat tokoh Gus Ipul akan dilihat terlebih dahulu daripada pemberitaan tentang kedatangan raja Arab. Karena karakter pembaca ingin tahu yang dikenalnya daripada yang tidak dikenalnya. Selanjutnya yang dilihat adalah berita yang dekat dengan headnews dan setelah featurenews yang dicari oleh pembaca adalah berita sekilas yang sifatnya menghibur dan mengisi kekosongan semata. alur baca pembaca terakhir tertuju pada footer sebagai kaki Surat kabar.

\section{KESIMPULAN}

Surat Kabar Harian Surya merupakan bagian dari media nasional yang menerbitkan, menyajikan berbagai ragam informasi kepada khalayak pembaca utama yakni masyarakat Jawa Timur. Di Surat kabar ini grid merupakan suatu kewajiban dalam pengaturan tataletak dikarenakan bidang yang luas dan untuk mempertahankan kesatuan. Tataletak media cetak pada dasarnya memiliki banyak unsur yang memiliki peran yang berbeda-beda dalam membangun kesatuan desain. Cover Surat Kabar Harian Surya menampilkan banyak berita unggulan yang dimuat dalam satu eksemplarnya tiap kali terbit. Tataletaknya pada anatomi suratkabar antara lain Header yang menampilkan nameplate, jargon, edisi, penerbit, dan mondatoris. Body menampilkan berita-berita yang perlu diklasifikasi berdasarkan urutannya. Antara lain headnews, featurenews dan berita sekilas. Unsur grid yang ada pada body antara lain Judul/headline, Margin, Jump, Artwork, Bullets, Bodytext, Caption, Foto, Headshot Footer menampilkan sponsorship. Tataan system grid pada cover surat kabar harian Surya yang menarik dengan tampilan 7 kolom yang fleksibel dengan alur baca atau hierarchical yang teratur akan memudahkan pembaca dalam memahami isi dari suratkabar tersebut.

Sistem Grid tidak hanya diperlukan pada Surat kabar. Media-media lain seperti Majalah, brosur, poster dan media periklanan lainnya memerlukan sistem grid supaya audiens paham dan terarah dalam membaca pesan yang ada pada media tersebut. Sehingga 
perlu adanya penelitian, tinjuan mengenai sistem grid pada media tersebut.

\section{DAFTAR PUSTAKA}

[1] Anggaraini S. Lia \& Natalia Kirana. 2014. Desain Komunikasi Visual. Bandung: Nuansa Cendekia.

[2] Moleong, Lexy, J. 2006. Metodologi Penelitian Kualitatif. Bandung: Rosdakrya

[3] Rustan, Surianto. 2008. Layout: Dasar dan Penerapannya. Jakarta: Gramedia

[4] Sihombing, Danton. 2015. Tipografi dalam Desain Grafis. Jakarta: Gramedia

[5] Suprayitno. 2012. Tinjauan Anatomi Layout Halaman Republika Epaper. Jurnal: Humaniora Vol.3 No.2 Oktober 2012: 593-605

[6] Tinarbuko, Sumbo. 2008. Semiotika Komunikasi Visual, Yogyakarta: Jalasutra

[7] Tondreau, Beth. 2009. Layout essentials: 100 design principles for using grids. Beverly, Massachusetts, USA: Rockport Publisher 